\title{
Measuring Success from Below: The Social Legitimacy of the United Nations among Populations Exposed to its Peacekeeping Operations
}

\author{
Amiad Haran Diman \\ Department of Political Science \\ The Hebrew University of Jerusalem \\ amiad.harandiman@mail.huji.ac.il
}

\section{Abstract}

The success of peacekeeping forces is both a topic of heated debate and a central theme in the literature on international peacekeeping. Most existing answers to this question rely on onedimensional macro-measures of effectiveness, such as battle fatalities. This paper proposes another perspective that is based on the point of view of local residents in countries that host United Nations peacekeepers. It argues that their support is an indicator of success, since they evaluate the institutional effectiveness of the peacekeepers they are exposed to. Using an aggregation of longitudinal data from the World Values Survey $(\mathrm{N}=25,196)$, and original data on the exposure to peacekeepers collected from the United Nations archives, we offer a unique, systematic and cross- national measurement of the local legitimacy of peacekeeping forces. Results from a multilevel, mixed-effects, linear model show significantly lower levels of confidence in the United Nations and higher levels of demand for the accountability of its forces in countries with an active peacekeeping operation. The level of confidence has a strong and negative correlation with the size of the mission, even when controlled for varied ideological explanations and for confidence extrapolation. The paper contributes to an ongoing debate on international peacekeeping and to research on the legitimacy of international organizations.

Acknowledgments: The author would like to thank Arie Kacowicz, Daniel Wajner and Georgina Y. Johnson for comments on earlier drafts of the paper. All of the responsibility on its contents are on the author alone.

word count: 9,907 including all elements FIRST DRAFT: 06.05.2020 THIS DRAFT: 18.10.2020 


\section{Introduction}

Are peacekeeping operations successful in stabilizing peace in post-conflict settings and in preventing the spread of armed violence? How should the success or failure of peacekeeping operations be measured? These are the seminal questions of international peacekeeping literature. Statistical studies use survival analysis to measure how much time peace lasts and peacekeeping's effect on it (Page Fortna 2004: 269, Page Fortna 2008, Caplan 2019: 74 - 103); or used spatial analysis to measure the effect of peacekeeping on the spread of battlefield deaths (Beardsley 2011: 1051). It has been found that peacekeeping is especially successful at settled conflicts but less so in active civil wars (Doyle et. al. 2006). These results have resisted several empirical challenges and have been repeated in studies that factor-in the non-randomness of peacekeeping deployment (Gilligan 2008: 89) or sub-national variance in deployment levels (Ruggeri et. al. 2017: 180). Yet, scholars have pointed out that the UN's peacekeeping record is spotted with failures, such as in Somalia, Rwanda, Angola and Bosnia (Howard 2012: 21 - 51). Scholars have also used field work to show that from the ground, the peacekeepers' contribution is questionable (Autesserre 2012: 41 - 83, Pouligny 2005). This is why: 'it remains contested whether peacekeeping works' (Ruggeri et. al. 2017: 163).

Much of the discussion is between qualitative researchers that find various problems in peacekeeping, and quantitative scholars that point out the positive effect shown by empirical findings on battle intensity and peace duration. Recently, there has been a surge of studies that investigate the role of legitimacy in conflict (Billeberck et. al. 2017: 273). The new emphasis on the local perspective includes various single-case studies that look at the effect of legitimacy in all parts of the conflict process (Duursma 2020: 295, Wajner 2020: 214, Gilbert 2020, Whalan 2017: 306, Billeberck 2017: 286, Richmond et. al. 2020: 261 - 86, Gippert 2017: 321). All of these studies, with the notable exception of Dursuma's, share common methodological constrains which include challenges in cross-national comparison, and a lack of systematic measurement. Legitimacy is hard to quantify, and different scholars could have contrasting views on it. This is why there is such a puzzling divide in opinion on peacekeeping success between scholars from different methodological schools - those who study the benefits of peacekeepers to the local population by interviewing them, and those who study it by analyzing battle event-data.

Therefore, this paper seeks to simultaneously fill two gaps at the intersection between the scholarship on peacekeeping and the legitimacy of international organizations. Firstly, the paper 
contributes to research on legitimacy in conflict processes by supplying, for the first time, an assessment of the legitimacy of a third actor in the conflict in a quantitative, systematic and crossnationally comparable way. It will use identical surveys conducted 19 different times by the World Values Survey project to analyze the impact of peacekeepers on the local legitimacy of UN in an objective and accurate manner. Secondly, the paper provides a unique contribution to the debate on peacekeeping's success by extending skeptical approaches that focused on the local population's viewpoint to incorporate quantitative data from various different settings. It will thus be a bridge between the scholars in the field, using the methodology of cross-national quantitative studies, while at the same time testing the approach of those who triumph field studies and listening to the actual people in the battlefield.

Is peacekeeping effective? In order to answer this question, support from conflict-affected citizens is treated as an indicator for mission success and as a synonym to legitimacy. The main research questions could be formulated as: 'What is the local legitimacy of United Nations in areas that host peacekeeping operations?'; and as 'How does exposure to United Nations peacekeeping forces affect the confidence of citizens in them?'. The paper will include a review of the relevant literature and we will argue that citizens' opinions are the best measure for peacekeeping evaluation since they are in a unique position to observe the effect of the forces on them and their country and because peacekeeping is sometimes justified on their behalf. The empirical section will include a detailed presentation and analysis of the data, identifying the effect of the size of peacekeeping forces on the confidence of the local population in them, which is measured by their trust in the United Nations. Finally, we will summarize and discuss the results with regard to their scholarly and policy implications.

\section{Global Governance, Legitimacy and Peacekeeping}

Ever since Joseph Nye (2001) raised the issue of the democratic deficit of globalization and the accountability of international institutions, there has been a growing concern about the legitimacy of global governance and the support of citizens for globalization. Buchanan and Keohane have argued that the legitimacy of international organizations should be assessed based on coordinated public support, particularly when carrying out consequential and controversial polices (2006: 417, 428), such as armed interventions. Contemporary empirical research on global governance is increasingly using large-N quantitative data to study the problem of legitimacy and its effect. For 
example, Dellmuth et. al. used the same data from the World Values Survey to test different mechanisms of support for the United Nations, treating local confidence as identical to social legitimacy (2015: 451). Duursma has shown that regional security organizations (Kacowicz et. al. 2016: 299) are more successful than global governance organizations in settling conflicts, precisely because they are considered more legitimate (Duursma 2020: 295). Their relative high legitimacy gives them the ability to legitimize actors in the conflict, even where substantial material support cannot be offered (Wajner et. al. 2018: 489).

In addition to the study of legitimacy and global governance, there is a longer tradition in security studies of focusing on the role of global governance in conflicts. Since the end of the 20th century, we have seen a dramatic rise in humanitarian interventions, in which many are led by the UN. These interventions include the use of peacekeeping forces, which are the main tool of the international community to resolve intrastate wars (Ruggeri et. al. 2017: 163). Both regional and global governance organizations carry out large scale peacekeeping operation in many fragile states, sometimes in cooperation, and increasingly in competition (Kacowicz 2018: 61, Weiss et. al. 2014: 904 -905). Resource problems strain the ability of regional organizations, in the case of the African Union for example, in large-scale peacekeeping operations. Both regional and global governance structures are still generally equally effective in defending civilians from governmental violence (Bara et. al. 2020: 341).

We find the intersection of research in both legitimacy and peacekeeping to be particularly important for the study of global governance. The main reason for this is that the dispatch of peacekeeping forces is the most serious breach of sovereignty and state power that an international organization can cause, even if it is limited and regulated. Even with the consent of host countries, it is still a breach of their monopoly on the control of violence and could be seen as a foreign invasion by nationalists. The countries in which interventions occur are also often not democracies, and the peacekeepers could be reenforcing the non-democratic rule, especially in cases of statebuilding after war. It is thus important for global organizations to justify military intervention with high legitimacy and citizen support, and in this, scholarship on legitimacy is highly relevant and important for United Nations peacekeeping operations. 


\section{The Importance of Local Legitimacy in Conflict Settings}

Social legitimacy risks being downgraded as a subject in comparison to outcomes of conflict resolution. Indeed, it is only marginally discussed in the literature on peacekeeping operations (Sabrow 2016:159). But we argue that social legitimacy is both practically necessary for successful peacekeeping missions and is also required for the United Nation's normative justification of them. We will also explain how local legitimacy is of importance for the academic community, and particularly why we see it as an indicator for mission effectiveness.

Multiple empirical studies have found that the trust of the local population is essential for the success of military campaigns, including of peacekeeping forces. In his canonical work on legitimacy, Webber argued that higher political legitimacy reduces violence and conflict within states (Schwarzenbach et. al. 2020: 1). Recent theories have further developed our insight into the importance of local support in war settings. For example, Kalyvas have famously identified the challenge faced by armed actors in civil wars from informational constrains. In order to identify essential information such as enemy location and the affiliation of citizens, armed actors use indiscriminate violence (2006: 146 - 172). Informational constraints are so severe and essential in the battlefield, that the only resort of armies to gather intelligence, if the population is not cooperating, is by harming it. The cause of deficits in information is found in the lack of cooperation from the population in the battlefield. United Nations peacekeepers cannot officially initiate attacks on civilians, so support from residents of the state is even more important in meeting this challenge.

This is particularly the case with modern 'peace enforcement' operations, such as in Mali, the Central African Republic, and the Democratic Republic of Congo (Karlsrud 2015: 40). In Mali, the peacekeepers are in the midst of a complicated counter-insurgency campaign and have lost many troops to bombing attacks. Lowering levels of legitimacy are correlated with an increase in terrorist attacks (Schwarzenbach et. al. 2020: 4 -6), and social support has been causally linked the success of counter-insurgency campaigns in field experiments. This emphasizes the need for social support in identifying insurgents among local populations (Matanock et. al. 2018: 800).

Legitimacy is also important for other types of operations, including peacebuilding and interstate peacekeeping. Civilian support is the key determinant for the success of peace settlements (Haas et. al. 2020: 982). Ruggeri et. al. have identified the fundamental role of peacekeepers, arguing 
that they must have the ability to reassure, deter or coerce armed actors, appearing as credible to them and also to the local population (2016: 163). Peacekeepers need to be able to persuade fighters to abstain from combat. Survey experiments show that local legitimacy is required to achieve this compliance from the local population, and that armed coercion does not have the same effect (Horne et. al. 2016: 454). Confidence in the peacekeepers will be associated with the population's belief in their power, which in turn will impact the degree of deterrence from the peacekeepers and trust in their reliability. These factors are necessary for peacekeeping in order to convince the factions that commitment to the peace agreement is credible, to reassure their fears, and to prevent new outbreaks of conflict. The legitimacy of a mission has also been linked to the degree of compliance with peacebuilding efforts from local office holders (Gippert 2015: 52). Finally, a practical concern is troop contributions: all United Nations operations rely on the voluntary decisions of states to donate parts of their armies for every operation (Bove et. al. 2020: 187, Bellamy et. al. 2013), sometimes due to a good relationship with the host state. Leaders will be reluctant to support any mission with low legitimacy, particularly if their citizens at home oppose it.

An additional problem for the United Nations in facing low levels of legitimacy is in the justification of the initiation of peacekeeping operations. The justification often appeals to international legitimacy, which is different from local or social legitimacy. It includes the use of arguments from international law, describing the conflict as a threat to international security, and securing formal endorsements for the mission from governments of the host state, the contributing states, and the Security Council member states. Although peacekeeping forces are accountable in practice to the United Nations and ultimately to the Security Council, they are often given the justification that they benefit the local population and protect innocent civilians (Hultman et. al. 2013: 875, Carnegie et. al. 2020). Even if they do in fact stop violence and promote peace, who are they doing it for? If the residents of states with peacekeeping presence oppose them, then why are they there?

Finally, and most importantly for this study, the local legitimacy of peacekeeping forces is important for scholars of international peacekeeping because, as we will argue in the next section, it is a new indicator for the success of peacekeeping. If peacekeeping operations are meant to serve the local population, then the satisfaction of that population with the peacekeepers is a central measure of effectiveness. If civilians are happy with the force, it is a sign that it has succeeded in 
its mission to serve and protect them - unless they dislike it for external reasons. We will show that the low confidence in the United Nations in areas with peacekeeping is not explained by the variables other than assessment of effectiveness, in order to demonstrate that legitimacy is indeed a sign of successful peacekeeping. Such extraneous factors include ideology, that causes some people to object to the UN despite its success in peacekeeping, or a general lack of trust in governmental or armed organizations. We will control these variables with other survey questions in order to isolate the effects of perceived success.

Indicators like battle intensity or conflict reoccurrence could be seen as one dimensional because they only take into account a single measurement, while the reality is far more complex. Civilians in conflict zones can offer a holistic and all-inclusive assessment of the peacekeepers since they consider all of their benefits and shortcomings and then calculate their support or opposition to it. Normal cross-national quantitative evidence will lead us to support peacekeeping because it observes its macro-level success in certain tasks, but qualitative research that is based on interviews with the local population could lead us to oppose it, because it observes misconduct by peacekeepers (Lee et. al. 2020) or ignorance with regard to the local setting (Pouligny 2005, Campbell 2018). This paper is unique in that it adopts the basic approach of the latter (empowering the local viewpoint when determining the effectiveness of peacekeepers) but use the methodology of the former (systematic, large-N, cross-national statistical analysis).

\section{Theoretical Framework}

Citizens in war zones where the United Nations has peacekeeping operation pay a certain price for that presence. This includes more abstract concession, such as the loss of some of the sovereignty of the country, and practical ones, such as having to deal with civilian victimization by the peacekeepers themselves and the additional proliferation of armed actors in the thousands of peacekeepers who join the war. In return for this cost, states and their population expect to get a trade-off in the form of successful peacekeeping - increased stability after conflict, limits on the spread of violence and the protection of civilians. Survey respondents weigh the costs they paid versus the benefits they got based on their real-time observation of the conduct and effectiveness of peacekeepers. It is possible that generally, like many studies suggest, peacekeepers succeed in some central goals. But the population can offer a deeper assessment of whether that is true in their case and if it was worth the costs attached to it. 
One main goal of peacekeeping is to protect civilians from violence and to provide basic security to residents of war-torn states. There has been a renewed scholarly interest in civilian protection by peacekeepers in recent years. Larger peacekeeping operations are generally corelated with significantly lower levels of civilian deaths (Hultman et. al. 2013: 875), especially if the peacekeeping force include peacekeepers from a diverse background (Bove et. al. 2015: 681). But Hultman also showed that the deployment of peacekeepers causes an upsurge in rebel violence against civilians in the short term (2010: 29). She argues that when combatants' sense a conflict is ending, it can induce them to attempt to change the balance of power to their favor. The resultant upsurge of violence against civilians includes attempts to quickly take territory or dominate populations, to impose costs on the opponent, or to profit financially from the war before the peacekeepers stop it (Hultman 2010: 32 - 34).

In the longer term, the local peacekeeping presence lowers the level of rebel violence but does not protect citizens from governmental violence (Fjelde 2018: 103). In fact, its ability to curb governmental violence is institutionally restricted because its conduct is based on state consent (Carnegie et. al. 2020). Therefore, the empirical study of civilian protection by peacekeepers suggests it has some contribution, but that peacekeeping is in practice still lacking and open to improvement.

Survey respondents might notice this spotty record and decide that it is not worth the risks and costs of welcoming the peacekeepers - and so they will object to it in the survey. Against the benefits of having a United Nations peacekeeping force in a fragile state, there are substantial risks for the local population. The contributing states for peacekeeping operations are mostly developing nations with problematic military records. The United Nations tries to reform the soldiers they send, but often fail (Sotomayor 2014: 68 -99). Peacekeepers have been tied to cases of rape in the Central African Republic (HRW, 2016) and in South Sudan (The Guardian, 2018). Studies have also found evidence of vast sexual exploitation in Haiti (Lee et. al. 2020, King et. al. 2020). Peacekeepers have also caused damage in an indirect way, for example by infecting Haiti with cholera for the first time in 30 years and causing the death of nearly ten thousand people. The United Nations took responsibility for this mistake only six years after the fact (The Guardian, 2016). It is reported that as a result of misconduct and failure to protect civilians, local protests against the peacekeepers erupted in Sudan, the CAR and the DRC (AFP, 2020, Al Jazeera, 2019) 
and it was claimed that the peacekeepers or the government responded to them with violence against the demonstrators (France24, 2016, Al Jazeera, 2019b).

Dellmuth et. al. have found that survey respondents decide their confidence in the United Nations in the same WVS data based on two mechanisms. One was their assessment of its institutional performance - if citizens witness that the organization is effective in solving problems and supply them with benefits, they will be more likely to support it (2015: 458 - 468). Respondents in countries with no heavy presence of United Nations activity will assess this based on secondhand reports or instinct.

In contrast, survey respondents in states that host United Nations peacekeeping forces are uniquely positioned to interact with the peacekeepers, observe their action or inaction and notice their effects on the state's conflict and levels of violence. The peacekeepers are the face of the United Nations in these states. The population exposed to peacekeepers will accordingly decide their level of confidence by evaluating their effectiveness. We propose that it is reasonable to assume that these respondent's institutional assessment of the United Nations, which will shape their declared confidence in it, will be based on this interaction with the peacekeepers.

The other mechanism that Dellmuth et. al. have found support for is confidence extrapolation the general level of confidence the responders have in any organization. We will control for the latter mechanism using a survey question on the respondent's confidence in other armed or governmental organizations. Sabrow has also shown that an assessment of the effectiveness of peacekeeping impacts the local legitimacy of peacekeeping missions, but she added an ideological mechanism that causes some people to have low confidence in the UN because of various political attitudes that have nothing to do with the missions' success, such as the normative stances of respondents, their sense of national pride, their support for the war the peacekeepers are stopping, and their general attitude to foreigners. By controlling variables that measure the ideology of the survey respondent, we will isolate the mechanism of institutional effectiveness and transform the local legitimacy of the UN to an indicator of its success in peacekeeping missions.

The population in host states evaluates the conduct of peacekeepers by comparing their effectiveness in protecting civilians and keeping the peace to their daily conduct in the interaction with civilians. If survey respondents' sense that the operation does not protect them or if it in fact harms them, they will declare lower levels of confidence. So, if an operation is not effective in 
their eyes it will decrease its levels of local legitimacy. This effect will be more pronounced as missions become bigger or last longer, as more citizens, and a larger part of the survey sample, will be exposed to it.

It is possible that other factors will cause survey respondents to denounce the peacekeepers even if they are effective. Alternative explanations need to be ruled out and a timetable specified in order to establish a link between exposure to peacekeeping and lower levels of confidence that is more causal, showing that these levels are actually the result of the non-effectiveness of the mission. We have only collected survey data from after the deployment of peacekeeping forces in order to base the deployment as the independent variable.

\section{Hypotheses}

United Nations peacekeeping forces have a positive impact on the macro level but are far from optimal. This is noticed by the population in conflict affected states, together with the misconduct of peacekeepers. As Dellmuth et. al. noted, the social legitimacy of the United Nations is based on the perceptions of its institutional performance. As previously explained, qualitative research has found that as seen from the ground, missions are not so successful. We accordingly expect that the population in host states assess the United Nations peacekeepers in a way which is more unfavorable than the assessment of populations that are not exposed to peacekeepers.

We thus hypothesize:

H1: The level of local legitimacy of the UN will be lower in states with a presence of a UN peacekeeping mission.

The local legitimacy can be pronounced in two ways, and so the first hypothesis can be divided into two. Social legitimacy could be based on local support, with the same conceptualization as Dellmuth et. al. But another key factor of legitimacy is accountability. In the WVS (World Values Survey) there are questions on the confidence in the United Nations and on who should decide and manage international peacekeeping: local governments, regional organization, or the United Nations. As described in the chapter on research design, we will use these two questions to operationalize legitimacy in two ways: by local support and by the demand for accountability. There is less data for the latter so this can only be incorporated in the assessment of the general 
effect of the presence on peacekeeping, and not when discussing the effect of the size of the mission and of alternative explanations.

Hla: The presence of a UN peacekeeping mission in a state weakens confidence in the UN among the state's local population.

$H 1 b$ : The presence of a UN peacekeeping mission in a state increases demand for local accountability in peacekeeping among the state's local population.

We stated earlier that larger missions will cause larger negative effects on the legitimacy of peacekeepers because a bigger part of the survey sample would have been exposed to peacekeepers which increases the chance of the formation of a negative opinion. Therefore:

H2: Larger UN peacekeeping missions in a state weakens confidence in the UN among the state's local population.

\section{Alternative Explanations and Control Variables}

It could be argued that even if the peacekeepers are successful and effective, citizens might nevertheless oppose the mission out of ideology. Sabrow has shown that the local legitimacy of peacekeepers in Mali was based on their perceived success and on ideological legitimacy (2016: 148). We would like to test if ideological reasons effect the link between the peacekeeping presence and local legitimacy in order to disprove that, and so to isolate legitimacy as an indicator of perceived success. For example, citizens who support war as a means to get justice will oppose the peacekeepers especially if they are successful in preventing war. We will test this hypothesis and others like it in order to show that they don't explain the opposition to the peacekeeping, which is in fact due to operational failures.

H3: Higher support for war will weaken the support for the UN among the local population in states that host a UN peacekeeping presence.

Another counterargument could lie in that the United Nations peacekeepers are successful in advancing progressive norms in the society, which is a key part of their mission (Björkdahl 2006). 
Some of the citizens, who belong to more conservative, backward thinking or traditionalist factions of the society, might object to this alien social development and so oppose the mission just because it was successful in this role. It is thus needed to test if:

H4: Higher opposition for norms that UN peacekeepers promote will weaken support for the UN among the local population in states that host a UN peacekeeping presence.

More specifically, peacekeepers have been trying to implement gender equality norms (Carey 2001), endorse norms of basic human rights (Anjum et. al. 2020), promote democracy and democratic norms (Sotomayor 2004), and to convince combatants not to use force for political means but to instead use civil and nonviolent political actions. In order to test for this, we split hypothesis four to four more precise sub-hypothesis:

H4a: Higher opposition to democracy will weaken the support for the UN among the local population in states that host a UN peacekeeping presence.

$H 4 b$ : Higher opposition to gender equality will weaken the support for the UN among the local population in states that host a UN peacekeeping presence.

$H 4 c$ : Higher support for political violence will weaken the support for the UN among the local population in states that host a UN peacekeeping presence.

H4d: Higher opposition to human rights will weaken the support for the UN among the local population in states that host a UN peacekeeping presence.

Another explanation for animosity towards the United Nations peacekeeping forces, that will persist even if the mission is successful, can be found in strong nationalistic tendencies. Some segments of the population might see the intervention of the United Nation as an insult to national pride and as a breach of its sovereignty. Even if the peacekeepers help the state, extreme nationalists might anyway oppose the mission out of principal. We will try to rule out such a hypothesis:

H5: Higher national pride of a citizen in a state with a UN peacekeeping presence will weaken the support for the UN among the state's local population. 
Similarly, some members of the local population may have anxious or even bigoted attitudes toward other nationalities. This mistrust in foreigners will cause them to object to the presence of peacekeepers, who come from other states, despite the possible aid they might offer.

H6: Lower levels of trust in other nationalities will weaken support for the UN among the local population in states that host a UN peacekeeping presence.

Finally, some people, especially in missions of peace stabilization after conflict, will not fear war anymore. In that case, missions that were successful at keeping the threat of war at bay and protecting civilians will anyway suffer from low levels of local legitimacy because they now seem redundant. In such a case, the social legitimacy of the peacekeeping forces will not indicate the success of the forces at all. It is important to test such an argument, even if only to disprove it:

H7: Higher levels of fear of war will cause higher support for the UN among the local population in states that host a UN peacekeeping presence.

Other than variables tied to ideological legitimacy (Sabrow 2016: 148), some survey respondents might declare low confidence in the UN due to reasons that have nothing to do with it. Dellmuth et. al. have found support for a mechanism in which citizens will evaluate their confidence in the UN based on their confidence in other institutions of governance, bureaucracy or military (2015: 458). If the local government and military have low levels of legitimacy, as is the case in many host states, the UN will also be perceived as illegitimate even if it is valued as effective in peacekeeping. We will control for confidence in armed forces and government in order to strike out this possibility:

H8a: Lower levels of local governmental legitimacy will lead to lower levels of the UN's social legitimacy.

$H 8 b$ : Lower levels of legitimacy of the local armed forces will lead to lower levels of the UN's perceived social legitimacy. 
In order to provide robust evidence in support of our argument that local legitimacy is a holistic indicator for peacekeeping effectiveness, we will seek to test and hopefully disprove hypothesis three to eight. In order to show that when success is conceptualized this way, peacekeeping is seen as ineffective, we will test and hopefully show evidence in support of hypothesis one and two.

\section{Research Design and Methodology}

The operationalization of the main independent variable, the extent of peacekeeping presence, is the simplest. We used the United Nations' online archives on peacekeeping, which contain all monthly reports to the secretary general of the size of peacekeeping operations. We identified all states that hosted a peacekeeping operation that have been surveyed by the WVS and identified the years when the survey was conducted. This includes 12 states that have been surveyed on 19 different occasions: Bosnia in 1998 and 2001; Croatia in 1996; Cyprus in 2006, 2011 and 2019; El Salvador in 1999; Ethiopia in 2007; Georgia in 1996, 2009 and 2014; Haiti in 2016; Iraq in 2004; Lebanon in 2013 and 2018; Macedonia in 1998 and 2001; Colombia in 2018; and Pakistan in 2019. We then take the size of every mission from the reports at the end of each year from when the war started to the time of the sampling of the survey. A simple mean was calculated to create the average size of every mission before the survey.

Therefore, a binominal variable $V P K O$ was created to indicate the existence of a UN peacekeeping presence. Its values are either 0 , to indicate no peacekeeping presence, or 1 , to indicate there is a peacekeeping presence. Overall, the 19 samples where $V P K O=1$ included a $\mathrm{N}$ of 25,196 respondents. The rest of the surveys includes a sample size of $\mathrm{N}=398,752$ that comes from states with no peacekeeping presence. Variable VPKsav indicates the average size of the peacekeeping operation, based on our calculation. It is ranged from 43 troops in the case of Pakistan to 10,600 troops in the case of Lebanon. The mean size was 2357.237 and the standard variation was 3005.592 .

In order to measure the social legitimacy of the peacekeepers we used the approach of Dellmuth et. al. and exploited a question that measures the confidence of respondents in the United Nations from the aggregation of all data from the World Values Survey, a series of cross-national identical surveys (Inglehart et. al. 2018). We propose that in states that host peacekeepers, there is a high correlation between confidence in the United Nations to confidence in the UN's peacekeepers, and 
so the answer of respondents in these states indirectly reflects the social legitimacy of the UN's peacekeepers. The respondents were asked the same question on many organizations: 'We are going to name a number of organizations. For each one, could you tell me how much confidence you have in them: The United Nations'. Responses could vary from 1 - A great deal, 2 - Quite a lot, 3 - Not very much and 4 - None at all. We cleaned the data from answers of 'I don't know' and where the question was not asked. We also reversed the scale so 4 will be very much and 1 is none at all, so a higher result will indicate higher social legitimacy. There were 317,285 answers given and the global mean was 2.438 with a standard deviation of 0.9588 . 22,949 of these answers were given in countries with UN peacekeeping. Because this question was asked in most surveys, we have a large amount of data and we use it as the primary indicator of local legitimacy and employ it in the main model as the dependent variable, represented through the continuous variable UNcon.

There was also another question that could indicate legitimacy: 'Who should decide about international peacekeeping? 1. National governments 2. United Nations 3. National governments, with UN coordination, 4. Regional organizations'. This gives an indicator of the demand for accountability, which is a facet of legitimacy. 106,916 people were asked this question but only 6,018 of them were in countries that host peacekeepers. It is therefore possible to test the difference in answers between countries with and without peacekeeping operations, but it is not possible to test the effect of the number of peacekeepers on answers because the variance in number is not big enough. That is why we tested how VPKO impacts answers to this question, but the main model with VPKsav only uses UNcon. We recoded the answers to the question to create an order of increasing demand for legitimacy, so 1 will still be national government but answer 2, the United Nations, will now be classified as 4, in the edge of the scale. The answer 4, Regional organization, was recoded to 2 . This created a continuous variable acountabilitypk in which lower answers reflect a call for local control on peacekeeping and higher answers reflect more support for the UN. The mean of the answers was 2.776 with a standard deviation of 1.274.

The control variables, alternative explanations that we seek to show have no effect on the correlation between VPKsav and UNcon, are all based on questions from the WVS. Support for war (from H3) was measured by the question 'Under some conditions, war is necessary to obtain justice. 1 - disagree, 2- agree'. This created a categorical variable that was named supwar. It has 
the mean value of 0.3497 and the standard deviation of 0.4769 , so most answers were 1 . It was asked 83,899 times, of which 5,135 were at states that host a peacekeeping operation.

Support for democracy (from $\mathrm{H4a}$ ) was measured by the question 'What is the importance of democracy from 1 - Not at all important to 10 - Absolutely important?'. This created a continuous variable that was named demosup. It has the mean value of 8.391 and the standard deviation of 2.081, so most answers were leaning towards high importance. It was asked 230,753 times, of which 14,940 were at host states.

Support for gender equality (from $H 4 b$ ) was measured by multiple questions that were grouped to a commonly used index, the Welzel index. This created a continuous variable that was named gendereqaul and represent support for gender equality in the political arena. It varies from 0 to 1 and has the mean value of 0.486 and the standard deviation of 0.325 , so the opinions of the respondents were split about whether gender equality is good in politics. It includes responses from 355,566 times, of which 24,379 were from states that host a peacekeeping operation.

Support for violence (from $\mathrm{H4c}$ ) was measured by the question 'Is violence against other people justifiable?', with answers ranging from 1 - Never justifiable to 10 - Always justifiable. This created a continuous variable that was named supviolence. It has the mean value of 1.95 and the standard deviation of 1.877 , so most answers were leaning towards never justifiable. It was asked 157,023 times, of which 11,016 were at host states.

Support for human rights (from $H 4 d$ ) was measured by the question 'In democracy, civil rights protect people's liberty from oppression' with answers ranging from 1 - Not an essential characteristic to 10 - an essential characteristic. This created a continuous variable that was named hrsup. It has the mean value of 7.594 and the standard deviation of 2.591, so most people thought it was essential. It was asked 221,725 times, of which 14,536 were at host states.

Nationalist attitudes (from H5) were measured by the question 'How proud are you of your nationality?' with answers ranging from 1 - very proud, to 4 - not at all proud. This created a continuous variable that was named nationalism. This has the mean value of 1.528 and the standard deviation of 0.741 , so most people in the global sample were patriotic. It was asked 470,580 times, of which 24,497 were at host states. 
Attitudes towards foreigners (from H6) were measured by the question 'How much do you trust people of another nationality?' with answers ranging from 1 - trust completely to 4 - do not trust at all. This created a continuous variable that was named trustforeign. It has the mean value of 2.815 and the standard deviation of 0.86 , so the sample is leaning towards mistrust. It was asked 217,776 times, of which 14,429 were at host states.

Fear from war (from $H 7$ ) was measured by the question 'Is one of your worries a war involving your country?' with answers ranging from 1 -very much to $4-$ not at all. This created a continuous variable that was named fearwar. It has the mean value of 2.06 and the standard deviation of 1.08 , so the global sample is almost equally split between those who worry and those who don't fear war. It was asked 153,925 times, of which 10,935 were at host states.

The legitimacy of the local government (from $\mathrm{H} 8 \mathrm{a}$ ) was measured by a question similar to the measurement of the UN's legitimacy: 'I am going to name a number of organizations. For each one, could you tell me how much confidence you have in them: The Government' when answers range from 1 - a great deal to 4 - not at all. We similarly reversed the scale so a higher answer will reflect higher legitimacy. This created a continuous variable that was named govleg. It has the mean value of 2.41 and the standard deviation of 0.954 . It was asked 360,169 times, of which 24,143 were at host states.

The legitimacy of the local armed forces (from $H 8 b$ ) was measured by a question similar to the measurement of the govleg: 'I am going to name a number of organizations. For each one, could you tell me how much confidence you have in them: The Armed Forces' when answers range from 1 - a great deal to 4 - not at all. We similarly reversed the scale so a higher answer will reflect higher legitimacy. This created a continuous variable that was named armyleg. It has the mean value of 2.801 and the standard deviation of 0.935. It was asked 390,083times, of which 24,440 were at host states.

The relationship between the variables will be tested using statistical analysis. $H 1$ will be answered with a T-test that compares the mean values of UNcon and acountabilitypk between the different groups in VPKO. I will also analyze with a T-test the effect of living in subnational regions where peacekeepers operate to regions far from the battlefield in order to show that the results are the same in the subnational level. I can do that on Lebanon, Georgia, Iraq and Cyprus because I have 
data on subnational deployment in these countries, while in many other cases it is not clear where the battlefield is, or the deployment is state-wide.

We will test all of the hypothesis from $H 2$ to $H 7$ by using a linear model in which UNcon is the dependent variable and VPKsav is the main independent variable. A key problem that doesn't allow the use of a standard Ordinary Least Squares regression is the different levels of analysis: 25,196 respondents that are organized into 19 groups. While every respondent has a different value at UNcon and other responses to questions, they share the same value of VPKsav with their group. In other words, the variance in the independent variable is limited and doesn't match the variance in the dependent variable. It can be shown with an analysis of variance (ANOVA) model on the sample, which will determine how much of the variance of UNcon is clustered in the country level. ANOVA suggests that the intra-class correlation $r$, the part of the variation of UNcon that is explained by the country level, is 0.1679 . This means that about $5 \%$ of the difference in the level of confidence in the United Nations could be predicted by the country the respondent lived in.

In order to account to the fact that the data contains variations in two levels, the state and the individual respondent, we will use two methods. One simple approach we will use is to calculate the average level of confidence in a state and then to compare it to VPKsav. In other words, we will shift the research design to be in only one level by making all of the variables' observations be in the state level. The drawbacks of this approach are that a lot of the depth of the data is lost and in the state level the $\mathrm{N}$ will only be 19, making it challenging to get significant results. It is also not viable to include the control variables in this calculation. We will therefore use it as a simple model that tests $H 2$ in this method with standard OLS and then use a more sophisticated method to analyze the interaction between all variables in the multilevel data.

For that purpose, we will employ the advanced method of multilevel mixed effects regression or hierarchical linear modelling (HLM). For example, this is used in cases when data from tests is analyzed and the students are organized into different classes. It is a form of linear regression in which the model accounts for the fact that the data is clustered into groups and exists in different levels. The regression model will include random intercepts at the group level of every sample. The model could be summarized in the following equation: 


$$
\begin{aligned}
\text { UNcon }_{i j}=\beta_{0} & +\beta_{1} \text { supwar }_{i j}+\beta_{2} \text { demosup }_{i j}+\beta_{3} \text { genderequal }_{i j}+\beta_{4} \text { supviolence }_{i j} \\
& +\beta_{5} \text { rsup }_{i j}+\beta_{6} \text { nationalism }_{i j}+\beta_{7} \text { trustforeign }_{i j}+\beta_{8} \text { fearwar }_{i j} \\
& +\beta_{9} \text { govleg }_{i j}+\beta_{10} \text { armyleg }_{i j}+\beta_{11} \text { VPKsav }_{i j}+\mu_{i}+\epsilon_{i j}
\end{aligned}
$$

when $i=43, \ldots, 10,600$ peacekeepers $, j=1, \ldots, 19$ samples, $\mathrm{u}_{\mathrm{j}}$ is the random effect and all other parts are normal components of a linear model.

\section{Results and Discussion}

The results from all of the statistical models support the theory that United Nations peacekeeping operations fail to win social legitimacy and the hypothesis that their presence leads to a decrease in their local legitimacy. Figure 1 describes the average level of confidence in the United Nations in every survey done in a country that hosts peacekeepers. As can be seen when observing the variation in countries that were surveyed multiple times, the level of legitimacy decreases as every mission prolongs.

FIGURE 1 AROUND HERE

$H \mathrm{Ha}$, the hypothesis stating that the presence of a peacekeeping operation decreases confidence in it, is corroborated by the two sample T-test with equal variance. The average confidence in the UN (UNcon) in countries with no peacekeeping operation $(V P K O=0)$ is 2.462 while the mean $U N c o n$ in host states $(V P K O=1)$ is 2.128 , a difference of -0.333518 or $10 \%$. We can determine that this different is negative in reality with a confidence interval of $99 \%(\operatorname{Pr}(\mathrm{T}>\mathrm{t})=0.000)$. 
$H 1 b$, the hypothesis stating that the presence of a peacekeeping operation increases demand for accountability and local control on it, is also corroborated by an additional two sample T-test with equal variance. The average trust in the UN's control of the peacekeeping operation (acountabilitypk) in countries with no peacekeeping operation $(V P K O=0)$ is 2.7988 while the mean acountabilitypk in host states $(V P K O=1)$ is 2.3966 , a difference of -0.4022 or $12 \%$. We can determine that this different is negative in reality with a confidence interval of $99 \%(\operatorname{Pr}(\mathrm{T}>\mathrm{t})=$ $0.000)$.

When comparing the average confidence in the subnational level, the findings are repeated. Regions with an active peacekeeping mission are less likely to support the UN than regions in the same states that do not host the actual peacekeeping bases. In Lebanon, Iraq, Haiti, Georgia and Cyprus the mean confidence in the UN is 2.349 in areas that are far from the battlefield and 2.019 in areas that have actual peacekeeping bases. Hence the UN has low legitimacy in the host states but even lower legitimacy in the regions that were most exposed to the peacekeepers. The difference is in fact $-0.3297,9.8 \%$ lower in regions with intense exposure to peacekeepers $(\operatorname{Pr}(\mathrm{T}>\mathrm{t})$ $=0.000)$, which confirms our expectation.

TABLE 1 AROUND HERE

When a simple OLS regression was performed on the mean level of legitimacy in every state and every year and the size of the peacekeeping, the results confirmed $H 2$. They were actually surprisingly strong and appear in Table 1 . Despite an $\mathrm{N}$ of 19 , we found a significant correlation between the size of the peacekeeping mission and its level of legitimacy $(\mathrm{p}=0.004)$. The coefficient is -0.000086 , suggesting that every additional peacekeeper added to the mission decreases the level 
of legitimacy by 0.000086 . A large mission with 10,000 troops will decrease the level of legitimacy by 0.86 or $25.8 \%$. By comparison, when using a Beta standardized coefficient, we found that the linear relationship is -0.6298057 , a strong correlation. The model explains $39.67 \%\left(r^{2}=0.3967\right)$ of the variation in legitimacy despite its simplicity. We can reject the null hypothesis and accept $H 2$, that larger exposure to peacekeeping decreases legitimacy, with a confidence level of $99 \%$. A representation of the correlation in a linear graph appears in Figure 2.

FIGURE 2 AROUND HERE

These results repeated even more strongly in the multilevel and multivariate model, although it is weighted to include controls for a variety of alternative explanations. When holding the effect of the alternative explanations as constant, an increase of 10,000 peacekeepers in a state will lead to a -1.079 decrease in the level of legitimacy or of $32.37 \%$. So, in this model we can reject the null hypothesis and accept $H 2$ with a confidence interval of $99 \%$ ( $\mathrm{p}=0.002$ ). The rest of the results of the hierarchical model are in Table 2. The linear relationship between exposure to peacekeeping and the operation's legitimacy is not explained by any of the alternative hypothesis ( $H 3$ to $H 7$ ). Thus, the results remain the same even when they are controlled. This increases the likelihood that 
social legitimacy is determined by the respondents' assessment of the effectiveness of the peacekeepers and not due to other variables.

Most alternative explanations didn't actually have any significant effect on the local legitimacy of the UN, except for support for violence (Coef. $=0.0158, \mathrm{p}<0.01$ ) and trust in people of other nationalities (Coef. $=-0.0548, \mathrm{p}<0.000)$ and the legitimacy of the government and military. Hypothesis $H 3, H 4 a, H 4 b, H 4 d, H 5$ and $H 7$ cannot be accepted because we cannot reject the null hypothesis, that they don't have an effect on the UN's legitimacy, while $H 6$ and $H 4 c$ can be accepted with a confidence interval of $95 \%$. The less an individual trusts foreigners, the lower the support for the peacekeepers will be, and the more an individual supports violence, the higher the chance of support for the UN. Additionally, we can reject the null hypothesis of $H 8 a$ and $H 8 b$ with a confidence interval of $99 \%$. The higher an individual's support for his government, the higher his support for the UN will be (Coef. 0.171, $\mathrm{p}<0.000$ ), and the higher an individual's support for his states' armed forces, the higher the support for the UN will be (Coef. 0.148, $\mathrm{p}<0.000$ ).

TABLE 2 AROUND HERE 
The final equation of the multilevel model, containing the results of the regression, will consequently be:

$$
\begin{aligned}
\text { UNcon }_{i j}= & 1.8566748-0.025 \text { supwar }_{i j}-0.007 \text { demosup }_{i j}+0.0176 \text { genderequal }_{i j} \\
& +0.011 \text { supviolence }_{i j}+0.0035 \text { hrsup }_{i j}+0.0785 \text { nationalism }_{i j} \\
& -0.05486 \text { trustforeign }_{i j}-0.024 \text { fearwar }_{i j}+0.171 \text { govleg }_{i j} \\
& +0.148 \text { armyleg }_{i j}-0.0001079 \text { VPSsav }_{i j}+\mu_{i}+\epsilon_{i j}
\end{aligned}
$$

\section{Conclusion}

This paper offers a stark warning for the United Nations' peacekeeping forces. They are faced with a challenge on their legitimacy that could even be classified as a crisis. UN peacekeepers have low levels of support from the population they are supposed to serve, and this support decreases in proportion to the increased exposure to peacekeepers of larger segments of the population. We have described the practical and normative importance of social legitimacy for peacekeeping, showing that this low legitimacy will make it harder for peacekeepers to succeed. Because we ruled out alternative explanations, it is highly possible that these low levels of legitimacy are the result of the population's view that the missions are unsuccessful and ineffective.

Peacekeeping forces risk falling into a downward spiral of illegitimacy: the missions are not successful enough to satisfy the population and so they have low legitimacy; this in turn makes it harder for them to improve and be successful. The results could suggest that the effectiveness of peacekeeping missions is lower in practice than what some studies suggest or that the extent of civilian victimization by the peacekeepers themselves is more widespread and has a deeper impact than we acknowledge. Future research could test this speculation more deeply and try to explain the low legitimacy in different ways. The UN should try to address the problem with better training for soldiers, increased accountability to local actors and improved aid to the population in conflict 
affected states. If it can deduce meaning from its current failure to gather social support and local legitimacy in areas of conflict it could find new purpose, becoming better equipped to legitimize its interference through future peacekeeping operations (Wajner 2019: 548).

This study helps bridge the gap in the international peacekeeping literature between the approach of scholars characterized by an emphasis on the local voices in host states to the scholarly approach that uses quantitative indicators to study the effect of peacekeeping on violence. We used a quantitative indicator for mission effectiveness that adopts the importance of the local viewpoint. The results contribute to the central debate on peacekeeping effectiveness and mainly supports those who argue that the UN is not very successful in peacekeeping. We also propose and employ a method to empirically quantify legitimacy of third actors in conflict processes. Future studies could use dedicated surveys of local populations in peacekeeping areas, as is being currently done in the after-exit project (Caplan 2019), to measure in a more precise manner the support for peacekeeping forces, the legitimacy of the peacekeepers, and the impact of the populations' exposure to the forces. Such a study could corroborate the finding from this paper, which are preliminary and exploratory.

\section{References}

Al Jazeera (2019a) Protests spread in east DRC as fury against UN peacekeepers rises. Accessed in 05.10.2020 in https://www.aljazeera.com/news/2019/11/27/protests-spread-in-eastdrc-as-fury-against-un-peacekeepers-rises.

Al Jazeera (2019b) Heavy gunfire erupts as DR Congo's anti-UN protests continue Accessed in 05.10.2020 in https://www.aljazeera.com/news/2019/12/2/heavy-gunfire-erupts-asdr-congos-anti-un-protests-continue

Anjum G, Chilton A, Usman Z (2020) United Nations Endorsement and Support for Human Rights: An Experiment on Women's Rights in Pakistan. Journal of Peace Research

Ashcraft, R. (ed.) (1991) John Locke: Critical Assessments. Routledge.

Autesserre, S. (2012) The Trouble with the Congo: Local Violence and the Failure of International Peacebuilding. Cambridge University Press

Bara, C. \& Hultman, L. (2020) Just Different Hats? Comparing UN and Non-UN Peacekeeping. International Peacekeeping, 27:3 
Beardsley, K. (2011) Peacekeeping and the Contagion of Armed Conflict. The Journal of Politics, 73:4

Bellamy, A. J. \& Williams, P. D. (Eds.) (2013) Providing Peacekeepers: The Politics, Challenges and Future of United Nations Peacekeeping Contributions. Oxford University Press

Björkdahl, A. (2006) Promoting norms through peacekeeping: UNPREDEP and conflict prevention, International Peacekeeping, 13:2

Billerbeck, S. B. K., \& Gippert, B. J. (2017) Legitimacy in Conflict: Concepts, Practices, Challenges, Journal of Intervention and Statebuilding, 11:3

Billerbeck, S. B. K (2017) UN Peace Operations and Conflicting Legitimacies, Journal of Intervention and Statebuilding, 11:3

Bode I, Karlsrud J. (2019) Implementation in practice: The use of force to protect civilians in United Nations peacekeeping. European Journal of International Relations. 25:2

Bove, V., Ruffa, C., \& Ruggeri, A. (2020) Composing Peace: Mission Composition in UN Peacekeeping. Oxford University Press.

Bove, V. \& Ruggeri, A. (2015) Kinds of Blue: Diversity in UN Peacekeeping Missions and Civilian Protection. The British Journal of Political Science 46:3

Buchanan, A. \& Keohane, R. O., (2006) The Legitimacy of Global Governance Institutions. Ethics \& International Affairs, 20:4

Campbell, S. (2018) Global Governance and Local Peace: Accountability and Performance in International Peacebuilding. Cambridge University Press

Caplan, R. (2019) The Foundations of a Research Agenda. International Peacekeeping

Caplan, R. and Hoeffler, A. (2019) Factors of Post Conflict Peace Stabilization. In Caplan, R., Measuring Peace: Principles, Practices, and Politics. Oxford University Press Carey, H. F. (2001) 'Women and peace and security': The politics of implementing gender sensitivity norms in peacekeeping, International Peacekeeping, 8:2

Carnegie, A. \& Mikulaschek, C. (2020) The Promise of Peacekeeping: Protecting Civilians in Civil War. International Organization, forthcoming

Dellmuth, L., \& Tallberg, J. (2015). The social legitimacy of international organisations: Interest representation, institutional performance, and confidence extrapolation in the United Nations. Review of International Studies, 41:3 
Doyle, M., \& Sambians, N. (2006) Making War and Building Peace: United Nations Peace Operations. Princeton University Press

Duursma, A. (2020a) African Solutions to African Challenges: The Role of Legitimacy in Mediating Civil Wars in Africa. International Organization, 74:2

Duursma, A. (2020b) Pinioning the Peacekeepers: Sovereignty, Host-State Resistance against Peacekeeping Missions, and Violence against Civilians, International Studies Review.

Gjelde, H., Hultman, L.\& Nilsson, D. (2018) Protection Through Presence: UN Peacekeeping and the Costs of Targeting Civilians. International Organization, 73:1

France24 (2016) Four killed in CAR protest against UN peacekeepers. Accessed on 05.10.2020 in https://www.france24.com/en/20161024-central-africa-republic-un-peacekeepersminusca-bangui

Gilbert, A. (2020) International Intervention and the Problem of Legitimacy: Encounters in Postwar Bosnia-Herzegovina. Cornell University Press

Gilligan, M. J. \& Sergenty, E. J. (2008) Do UN Interventions Cause Peace? Using Matching to Improve Causal Inference. Quarterly Journal of Political Science, 7:3

Gippert, B. H. (2017) Legitimacy and Coercion in Peacebuilding: A Balancing Act, Journal of Intervention and Statebuilding, 11:3

Gippets, B. J. (2015) Exploring Local Compliance with Peacebuilding Reforms: Legitimacy, Coercion and Reward-Seeking in Police Reform in Kosovo. International Peacekeeping, 23:1

Haas, N. \& Khadka, P. B. (2020) If They Endorse It, I Can't Trust It: How Outgroup Leader Endorsements Undercut Public Support for Civil War Peace Settlements. American Journal of Political Science, 64:4

Howard, L. M. (2012) UN Peacekeeping in Civil Wars. Cambridge University Press.

Hultman, L. (2010) Keeping Peace or Spurring Violence? Unintended Effects of Peace Operations on Violence Against Civilians. Civil Wars, 12:1

Hultman, L., Kathman, J. \& Shnnon, M. (2013) United Nations Peacekeeping and Civilian Protection in Civil War. American Journal of Political Science. 57:4

Human Rights Watch (2016) Central African Republic: Rape by Peacekeepers. Accessed on 05/10/2020 in https://www.hrw.org/news/2016/02/04/central-african-republic-rapepeacekeepers 
Inglehart, R., Haerpfer, C., Moreno, A., Welzel, C., Kizilova, K., Diez-Medrano, J., Lagos, M., Norris, P., Ponarin, E. \& Puranen B. (eds.) (2018) World Values Survey: All Rounds - Country-Pooled Datafile Version. Madrid: JD Systems Institute.

Kacowicz, A. M. \& Press-Barnathan, G. (2016) Regional Security Governance. In Borzel, T. A. \& Risse, T. (Eds.) The Oxford Handbook of Comparative Regionalism.

Kacowicz, A. M. (2018) Regional Governance and Global Governance: Links and Explanations. Global Governance, 24

Kalyvas, S. N. (2006) The Logic of Violence in Civil War. Cambridge University Press Karlsrud, J. (2015) The UN at war: examining the consequences of peace-enforcement mandates for the UN peacekeeping operations in the CAR, the DRC and Mali. International Peacekeeping, 36:1

Keohane, R. O. (2011) Global Governance and Legitimacy. Review of International Political Economy, 18:1

King, C., Lee, S. \& Bartels, S.A. (2020) 'They Were Going to the Beach, Acting Like Tourists, Drinking, Chasing Girls': A Mixed-Methods Study on Community Perceptions of Sexual Exploitation and Abuse by UN Peacekeepers in Haiti. Stability: International Journal of Security and Development, 9:1

Lee, S. \& Bartels, S. A. (2020) 'They Put a Few Coins in Your Hand to Drop a Baby in You': A Study of Peacekeeper-fathered Children in Haiti, International Peacekeeping, 27:2 Matanock, A. M. \& Garcia-Sanchez, M. (2017) Does Counterinsurgent Success Match Social Support? Evidence from a Survey Experiment in Colombia. The Journal of Politics, 80:3

Nye, J. (2001). Globalization's Democratic Deficit: How to Make International Institutions More Accountable. Foreign Affairs, 80:4.

Page Fortna, V. (2008) Does Peacekeeping Work? Shaping Belligerents' Choices After Civil War. Princeton University Press.

Page Fortna, V. (2004) Does Peacekeeping Keep Peace? International Intervention and the Duration of Peace After Civil War. International Studies Quarterly, 48:2

Pilkington, E., \& Quin, B. (2016) UN Admits for First Time That Peacekeepers Brought Cholera to Haiti. The Guardian, Accessed on 25.9.2020 at https://www.theguardian.com/globaldevelopment/2016/dec/01/haiti-cholera-outbreak-stain-on-reputation-un-says 
Pouligny, B. (2005) Peace Operations Seen from Below: UN Missions and Local People. Hurst Publication

Richmond, O. P., \& Mac Ginty R., Ed. (2020) Local Legitimacy and International Peacebuilding. Edinburgh University Press

Ruggeri, A., Dorussen, H., \& Gizelis, T. (2017). Winning the Peace Locally: UN Peacekeeping and Local Conflict. International Organization, 71:1

Sabrow, S. (2016) Local Perceptions of the Legitimacy of Peace Operations by the UN, Regional Organizations and Individual States - a Case Study of the Mali Conflict. International Peacekeeping, 24:1

Schwarzenbach, A., \& LaFree, G. (2020) Political Legitimacy and Worldwide Terrorist Attacks, 1970-2017. Working Paper - APSA Preprints Comparative Politics

Soyomayor, A. (2014) The Myth of the Democratic Peacekeeper: Civil - Military Relations and the United Nations. Johns Hopkins University Press

The Guardian - Pilkington, E., \& Quin, B. (2016) UN Admits for First Time That Peacekeepers Brought Cholera to Haiti., Accessed on 25.9.2020 at https://www.theguardian.com/global-development/2016/dec/01/haiti-cholera-outbreak-stain-onreputation-un-says

The Guardian - AFP (2018) UN peacekeepers accused of child rape in South Sudan, Accessed on 05.10.2020 at https://www.theguardian.com/world/2018/apr/24/un-peacekeepersaccused-of-child-in-south-sudan

Wajner, D. \& Kacowicz, A. M. (2018) The Quest for Regional Legitimation: Analyzing the Arab League's Legitimizing Role in the Arab Spring. Regional \& Federal Studies, 28:4

Wajner, D. (2019) Learning for Legitimacy: The Gaza Flotilla Case of Meaningful Learning in Foreign-Policy Strategic Planning. Foreign Policy Analysis, 15:4

Wajner, D. (2020) International Legitimacy and Conflict Resolution: Analyzing Legitimation Dynamics During Peace Negotiations in Intractable Conflicts. Ph.D. thesis, the Hebrew University of Jerusalem

Weiss, T.G. \& Welz, M. (2014), The UN and the African Union in Mali and beyond: a shotgun wedding? International Affairs, 90

Whalan, J. (2017) The Local Legitimacy of Peacekeepers, Journal of Intervention and Statebuilding, 11:3 